\title{
Employee Relations Dalam Isu Penutupan Perusahaan (Studi Kasus Gerai Matahari Di Mall Pluit Village)
}

\author{
Jasmin Wati, Farid \\ jasminwati@yahoo.com,,farid@fikom.untar.ac.id \\ Fakultas Ilmu Komunikasi Universitas Tarumanagara
}

\begin{abstract}
Matahari is a chain of shops selling clothes and other clothing. In the last few years the Sun is rife with the issue of closing down its outlets in Jakarta and several regions in Indonesia. Employee Relations is a process of managing and maintaining a harmonious relationship between company management and employees. Employee Relations is very important because it can create a healthy and positive company climate. Indirectly employee relations activities can affect the harmonious relationship between the company and employees. The purpose of this study was to determine how the employee relations activities in dealing with the issue of closing the solar outlet. Theories used in this research are Employee Relations and Public Relations. The research method used in this study was qualitative by interviewing Store Manager, Assistant Store Manager and Personnel Supervisor of Gerai Matahari Pluit Village. The findings of this study indicate that employee relations activities play an important role in building good relations with Gerai Matahari Mall Pluit Village employees. This can provide internal peace for employees amid the issue of closing the Sun Outlet
\end{abstract}

Keywords: employee relations, solar outlets, public relations, corporate closure issues

\begin{abstract}
Abstrak
Gerai Matahari adalah sebuah jaringan toko yang menjual baju dan pakaian lainnya. Dalam beberapa tahun terakhir Matahari marak dengan isu penutupan gerainya di Jakarta dan beberapa daerah di Indonesia. Employee Relations adalah sebuah proses mengatur dan memelihara hubungan harmonis antara pihak manajemen perusahaan dengan karyawan. Employee Relations sangat penting dilakukan karena dapat menciptakan iklim perusahaan yang sehat dan positif. Secara tidak langsung kegiatan employee relations dapat mempengaruhi hubungan yang harmonis antara perusahaan dan karyawan. Tujuan penelitian ini adalah untuk mengetahui bagaimana kegiatan employee relations dalam menangani isu penutupan gerai matahari tersebut. Teori yang digunakan dalam penelitian ini adalah Employee Relations dan Public Relations. Metode penelitian yang digunakan dalam penelitian ini adalah kualitatif dengan mewawancarai Store Manager, Assistant Store Manager dan Personalia Supervisor Gerai Matahari Pluit Village. Hasil temuan dari penelitian ini menunjukkan bahwa kegiatan employee relations berperan penting dalam membangun hubungan baik karyawan Gerai Matahari Mall Pluit Village. Hal ini bisa memberi ketenangan bagi internal karyawan di tengah isu penutupan Gerai Matahari.
\end{abstract}

Kata kunci: employee relations, gerai matahari, public relations, isu penutupan perusahaan

\section{Pendahuluan}

Saat ini persaingan bisnis retail semakin marak dan ketat. Bisnis retail merupakan sebuah usaha bisnis yang bergerak di bidang penjualan barang seperti department store dan toko. Konsep department store tersebut lahir dari penggabungan beberapa toko yang berbeda, dimana terletak di dalam satu lokasi yang sama serta merupakan sebuah toko skala besar untuk melakukan penjualan berbagai macam 
barang. Salah satu departement store yang ada di Indonesia saat ini adalah Matahari yang menyediakan perlengkapan pakaian, aksesoris, produk kecatikan, dan rumah tangga.

Saat ini gerai Matahari mengalami transisi menghadapi perubahan-perubahan yang terjadi. Sebagai dampak persaingan yang semakin ketat, gerai Matahari harus menutup beberapa gerai nya di Indonesia, seperti di Surabaya dan Bandung. Di Jakarta sendiri, sejumlah gerai Matahari di Mall Taman Anggrek dan Blok M sudah ditutup. Tapi beberapa gerai masih ada yang buka, salah satunya di Mall Pluit Village.

Penelitian ini ingin mengetahui bagaimana manajemen gerai Matahari Mall Pluit Village melakukan employee relations terhadap karyawannya di tengah isu penutupan gerainya tersebut.

\section{Metode Penelitian}

Jenis penelitian yang digunakan dalam penelitian ini adalah deskriptif dengan pendekatan kualitatif. Alasan peneliti menggunakan jenis penelitian deskriptif kualitatif karena dalam penelitian ini data-data yang dikumpulkan berupa kata-kata, gambar dan bukan angka-angka (Moleong, 2002:6). Dengan demikian laporan penelitian akan berisi kutipan - kutipan data untuk memberikan gambaran penyajian laporan tersebut. Data yang diambil berasal dari wawancara, catatan lapangan, dokumen pribadi dan dokumen resmi lainnya.

Adapun yang menjadi narasumber dari penelitian ini adalah Public Relations, Store Manager, Assitant Store Manager, dan Personalia. Selain itu Peneliti juga mewawancarai Supervisor yang bertugas mengawasi karyawan. Peneliti juga mewawancarai Staff Kasir dan Pramuniaga mewakili Karyawan Matahari.

\section{Hasil Penelitian dan Diskusi}

Karyawan di dalam sebuah perusahaan merupakan sebuah aset yang penting dan merupakan ujung tombak perusahaan dan di dalam Public Relations dikenal dengan hubungan masyarakat internal (Employee Relations), yaitu publik yang terdiri dari para pekerja (karyawan) menjadi bagian utama dari unit usaha, perusahaan atau sebuah institusi.

Matahari juga memahami bahwa karyawan memiliki peran penting kesuksesan perusahaan. Perusahaan sangat memahami dengan jelas bahwa apabila karyawan bekerja dengan baik maka hasil yang diperoleh perusahaan akan lebih menguntungkan begitu pula sebaliknya apabila para karyawan tidak bekerja dengan baik maka kemungkinan perusahaan juga akan mengalami kerugian. Dari kutipan wawancara yang peneliti lakukan bersama Supervisor Hr Matahari Mall Pluit, mereka sangat memahami pentingnya karyawan di dalam perusahaan terutama untuk mereka yang langsung berhadapan dengan konsumen. Berikut kutipan hasil wawancara tersebut:

"Kalau pentingnya karyawan bagi perusahaan seperti contohnya sebuah kapal, kita ini sebagai Supervisor adalah nahkodanya dan mereka adalah awak kapalnya, kalau tanpa ada awak kapal kita tidak bisa menjalankan sebuah kapal. Jadi di dalam perusahaan pasti kita selalu membutuhkan karyawan. Karena tanpa adanya karyawan di suatu perusahaan maka perushaan tersebut juga pasti akan kesulitan dan perusahaan tersebut tidak bisa menjalankan kegiatan usahanya dengan baik. 
Matahari merupakan perusahaan yang menawarkan produk kepada customernya seperti produk fashion mulai dari wanita, pria sampai fashion anak juga tersedia di Matahari, selain itu juga Matahari menyediakan produk yang lainnya seperti produk kecantikan dan masih banyak lagi. Dalam proses usahaanya Matahari melakukan proses jual beli yang dimana harus terdapat pelayanan yang prima agar konsumen merasa puas dengan pelayanan yang diberikan sehingga hal ini dapat membuat konsumen bisa kembali lagi untuk berbelanja di Matahari.

Dari hasil wawancara di atas dapat disimpulkan bahwa karyawan sangatlah berperan penting dalam perusahaan, dimana setiap bagian saling membutuhkan satu sama lain, tanpa adanya karyawan maka perusahaan pasti akan kesulitan dan tidak bisa menjalankan usahanya dengan baik.

Untuk membangun interaksi yang baik di dalam perusahaan tentunya harus ada hubungan yang baik pula diantara setiap karyawan, baik itu hubungan kepada pimpinan maupun hubungan kepada sesama karyawan. Dengan membangun hubungan yang baik maka akan terjalin rasa saling percaya, rasa untuk saling tolong dalam pekerjaan sehingga membuat pekerjaan menjadi lebih mudah untuk dilakukan. Di Matahari Mall Pluit sendiri berusaha untuk selalu membangun hubungan yang baik dengan setiap karyawannya. Perusahaan bertujuan untuk membuat lingkungan pekerjaan yang ada di gerai seperti hubungan kekeluargaan, dimana apabila terjadi kendala di dalam melakukan pekerjaan ataupun hasil kerja yang kurang memuaskan maka akan langsung dibicarakan dengan pihak yang bersangkutan.

Hubungan yang baik di dalam perusahaan dibangun tujuannya adalah menjadikan lingkungan kerja menjadi tempat yang nyaman bagi karyawan sehingga setiap karyawan bisa melakukan tugas dan tanggungjawabnya dengan baik. Dengan hubungan yang baik akan menghindari terjadinya konflik dan perselisihan antar karyawan yang menyebabkan lingkungan kerja menjadi tidak nyaman dan dapat menghambat kinerja dari karyawan. Begitu juga yang dikatakan Supervisor HR dalam hasil wawancara, kutipan wawancara tersebut adalah sebagai berikut:

"Kalau menilai karyawan yang di matahari mall pluit village yang pastinya saya akan tetap selalu memantau mereka. Sejauh dari pengalaman saya sendiri kita ini memang dibangun untuk dibentuk dalam suatu wadah tersendiri untuk menghubungkan dengan para karyawan, manajemen, atau ikatan kerja matahari. Mereka selalu mengerjakan tugas masing masing secara baik. Kalau hubungan untuk sejauh ini tidak pernah terjadi konflik, tidak pernah ada kendala atau perselisihan karyawan dengan karyawan, karyawan dengan atasan.

Selanjutnya peneliti melakukan wawancara mengenai hal yang sama dengan kasir Matahari Mall Pluit yang pada saat itu sedang melakukan tugasnya. Di bawah ini hasil wawancaranya.

Kalau hubungan sih semuanya baik, sama atasan baik sama karyawan yang lain juga baik, tidak ada masalah yang terjadi.

Berdasarkan pendapat yang dijelaskan karyawan di Matahari Mall Pluit baik itu pimpinan maupun karywannya bahwa hubungan yang terjalin di Matahari Mall Pluit seperti hubungan keluarga, pimpinan berupaya untuk menjadikan lingkungan kerja di Matahari tersebut seperti hubungan keluarga sehingga karyawan bisa merasa nyaman dalam melakukan pekerjaannya. Pimpinan terus berusaha untuk melakukan pendekatan kepada karyawan dengan selalu memberikan dukungan dan motivasi guna 
untuk meningkatkan kinerja yang nantinya juga akan memberikan keuntungan bagi perusahaan. Hubungan antara sesama karyawan juga terjalin dengan baik, tidak pernah ada terjadi konflik maupun perselisihan, bekerja dengan saling membantu satu sama lain membuat hubungan karyawan semakin kuat sehingga dalam melakukan tugasnya selalu merasa nyaman.

\section{Kegiatan Employee Relations}

Karyawan di dalam perusahaan merupakan aset yang sangat penting dan dalam dunia public relations dikenal dengan hubungan masyarakat internal (employee relations) yaitu publik yang terdiri dari para pekerja (karyawan) menjadi bagian utama dari unit usaha perusahaan itu sendiri. Untuk itu adanya kegiatan employee relations disebuah perusahaan sangatlah penting untuk dilakukan. Tujuan diadakannya kegiatan employee relations adalah untuk memperkuat hubungan yang terjalin di dalam sebuah perusahaan, memperkuat teamwork guna untuk mencapai target sasaran dan untuk lebih mendalami dan mengenal karakteristik dan sifat dari karyawan yang bekerja baik pimpinan kepada karyawan maupun sebaliknya serta antar sesama karyawan. Dalam wawancara yang peneliti laukakan dengan Supervisor HR mengenai tujuan dari kegiatan employee relations yang diadakan, beliau mengatakan bahwa tujuan diadakan kegiatan ini yang pastinya untuk membangun suatu tim, karena kalau tidak ada kekompakan di dalam suatu team juga pasti tidak akan bisa maju..

Adapun kegiatan employee relations yang dilakukan Matahari Mall Pluit Village dalam menjaga hubungan baik dengan para karyawannya yang peneliti peroleh melalui wawancara dengan Supervisor HR adalah sebagai berikut :

Kegiatan employee relation yang diterapkan di mall pluit village selama ini biasanya kita selalu ada bagi-bagi pekerjaan masing-masing untuk perharinya, misalnya perharinya itu kita kerjakan apa saja, apa saja kegiatannya, biasanya dari hari Senin kegiatannya ada 5R itu ngapain saja. yang paling sering kalau untuk employee relation itu setiap setahun sekali itu selalu ada yang dinamakan membangun kerjasama untuk anak-anak karyawan. Jadi bisa kEtahuan kalau karyawan nya begini, atau stafnya begini, maupun atasannya. Jadi 5R itu artinya bagaimana untuk kita bisa kerjasama membangun toko ini misalnya dalam hal kebersihan pada saat itu mereka harus ikut serta semua.

Dari penjelasan yang telah diberikan oleh Supervisor HR bahwa kegiatan employee relations yang diadakan di Matahari Mall Pluit adalah pekerjaan yang dilakukan setiap harinya, kegiatan $5 \mathrm{R}$ yaitu kegiatan dalam hal kebersihan toko dan ada kegiatan tahunan yang dilakukan untuk membangun hubungan kerjasama dengan karyawan.

Dalam kegiatan employee relations tujuannya adalah membangun hubungan yang baik dengan karyawan, keterlibatan manajemen dan karyawan sangat penting karena untuk membangun suatu hubungan yang baik harus ada pertemuan diantara keduanya. Hal ini juga berguna untuk merencanakan strategi-strategi yang akan diambil perusahaan kedepannya. Seperti yan disampaikan oleh Supervisor HR dalam wawancara mengenai keterlibatannya dalam kegiatan employee relations, berikut kutipan wawancaranya:

Kalau keterlibatan dalam kegiatan-kegiatan pasti ada karena kalau kita membentuk suatu team kita harus ada starategi juga agar tidak ada 
ketimpangan. Pengalaman saya sebagai HRD perbedaannya kalau ketika saya berbicara dengan HRD yang lain bedanya anak-anak zaman sekarang sama zaman dulu berbeda. Jadi anak-anak zaman sekarang kalau kita sebagai atasan kita bukan hanya cuma menyuruh saja, tetapi kita juga harus sama-sama ikut membantu juga.

Lebih lanjut peneliti menanyakan mengenai partisipasi karyawan dalam kegiatan-kegiatan employee relations tersebut. Berikut penjelasannya:

Kalau menurut saya mereka selalu ikut serta langsung dalam kegiatan hal apapun biasanya matahari selalu mengadakan program 5R itu mereka semua pasti akan ikut serta juga karena memang mereka semua banyak yang suka dalam melakukan kegiatan apapun karena ini semua untuk tujuan bersama bukan tujan diri sendiri.

Selanjutnya peneliti mewawancarai bagian kasir mengenai hal yang sama, yaitu bagaimana keterlibatannya dalam kegiatan employee relations, berikut penjelasan yang diberikan dalam wawancara:

Kalau keterlibatan biasanya ke bagian supervisor contohnya kalau customer menanyakan size.

Begitu juga dengan keterlibatan karyawan yang lainnya yang dinilai bagus berdasarkan dari pendapat kasir tersebut.

\section{Partisipasi Employee Relation (Supervisor)}

Dari hasil tersebut dapat dikatakan bahwa dalam setiap kegiatan employee relations baik pimpinan (Supervisor) maupun karyawan ikut terlibat dan mengikuti kegitan-kegitan tersebut. Supervisor sebagai pimpinan ikut terlibat dalam kegiatan agar dapat membentuk sebuah team dan dapat merencanakan strategi untuk perusahaan kedepannya. Karyawan Matahari Mall pluit juga ikut mengambil peran dan berpartisipasi dalam setiap kegiatan tersebut sehingga dapat terjalin hubungan yang baik dengan atasan.

Dari kegiatan-kegiatan employee relaitons tersebut tentulah ada manfaat yang didapatkan oleh setiap karyawan yang mengikutinya. Adapun manfaat yang didapatkan berdasarkan wawancara dengan Supervisor HR dan Kasir adalah sebagai berikut:

Manfaat yang dapat dirasakan dengan adanya program-program tersebut, jadi kita semua tidak terjadi ketimpangan dan masing-masing juga sudah tau apa saja yang harus mereka kerjakan dan juga ada jobdesk masing-masing.

Lebih lanjut penjelasan yang diberikan Kasir adalah sebagai berikut:

Kalau manfaat misalnya ada barang yang di display itu dari yang kita tidak tau sekarang jadi tau. Dan selain itu jadi mendapatkan suatu pengalaman

Untuk penyampaian informasi mengenai setiap kegiatan employee relations tersebut, di Matahari Mall di sediakan kotak saran sebagai media penyampaian pendapat dan saran untuk manajemen apa saja yang harus dilakukan kedepannya untuk kemajuan Matahari Mall Pluit dan juga ada yang namanya suara matahari sebagai media internalnya. Seperti yang disampaikan Supervisor HR sebagai berikut: 
Kalau untuk media penyampaian informasi kita disini ada kotak saran jadi kotak saran ini berfungsi apa saja yang harus kita lakukan utuk kemajuan toko ini. Kalau untuk close staff ke manajemen itu bisa pake suara matahari khususnya. Jadi sudah bisa kedengaran suaranya.

Sebelum kegiatan-kegiatan employee relations itu dilakukan tentunya ada tahap perencanaan yang dilakukan oleh pihak manajemen Matahari Mall Pluit agar kegiatan-kegiatan tersebut dapat berjalan dengan baik dan lancar dan tidak ada masalah yang terjadi dalam kegiatan yang dilakukan. Supervisor HR menjelaskan tahap perencanaan kegiatan employee relations, yaitu sebagai berikut:

Proses perencanaan awal sebelum menerapkan kegiatan employee relation semua kegiatan employee relation itu kita membentuk suatu team dalam perusahaan misalnya apa saja yang kita boleh kerjakan dan apa saya yang tidak boleh dikerjakan.

Setelah kegiatan-kegiatan tersebut dilakukan maka harus diadakan evaluasi agar dalam menjalankan kegiatan-kegiatan employee relations tersebut dapat terus berjalan dengan baik dan tidak ada masalah yang terjadi.

Dari hasil wawancara di atas dapat disimpulkan bahwa media internal yang digunakan adalah kotak saran dan suara Matahari. Untuk perencanaannya sendiri dalam proses kegiatan employee relations adalah dengan membentuk sebuah tim agar dapat merencanakan strategi apa yang harus dilakukan dan pembagian tugas masingmasing. Sedangkan untuk evaluasi kegiatan employee relaitons tersebut Matahari Mall Pluit mempunya program sendiri yang tidak dijelaskan kepada peneliti.

\section{Kesimpulan}

Berdasarkan hasil analisis dan pembahasan pada bab sebelumnya maka dapat diambil kesimpulan yaitu Employee Relation sangatlah berperan penting bagi Matahari Mall Pluit, dimana setiap bagian saling membutuhkan satu sama lain, tanpa adanya karyawan maka perusahaan pasti akan kesulitan dan tidak bisa menjalankan usahanya dengan baik.

Kegiatan employee relations yang ada di Matahari Mall Pluit pekerjaan yang dilakukan setiap harinya, kegiatan $5 \mathrm{R}$ yaitu kegiatan dalam hal kebersihan toko dan ada kegiatan tahunan yang dilakukan untuk membangun hubungan kerjasama dengan karyawan. Dalam kegiatan employee relations tujuannya adalah membangun hubungan yang baik dengan karyawan, keterlibatan manajemen dan karyawan sangat penting karena untuk membangun suatu hubungan yang baik harus ada pertemuan diantara keduanya.

Komunikasi internal yang terjadi di Matahari Mall Pluit dalam aktivitasnya sehari-hari yaitu berupa komunikasi internal vertikal dan horizontal, dimana komunikasi vertikal yaitu atasan akan menyampaikan informasi kepada karyawan melalui supervisor masing-masing terlebih dahulu setelah itu baru akan disampaikan kepada semua karyawan, begitu juga apabila karyawan memiliki pendapat akan menyampaikan sepada supervisor terlebih dahulu setelah itu baru akan disampaikan kepada atasan ataupun karyawan menyampaikan pendapatnya melalui kotak saran. Komunikasi horizaontal yaitu sesama karyawan akan saling memberikan informasi yang mereka dapat mengenai pekerjaan ataupun perusahaan sehingga terjalin hubungan yang baik antar sesama karyawan 
Jasmin Wati, Farid : Employee Relations Dalam Isu Penutupan Perusahaan (Studi Kasus Gerai Matahari Di Mall Pluit Village)

\section{Ucapan Terima Kasih}

Penulis mengucapkan terima kasih kepada pihak pihak yang telah memberikan sumbang saran pengetahuannya, terutama kepada dosen pembimbing Pak Farid, S.S, M. Si yang telah memberikan saran pendapat dalam penyelesaian skripsi dan penulisan jurnal.

\section{Daftar Pustaka}

Cutlip, S., Center, A. H., \& Broom, G. M. (2009). Effective Public Relations Edisi Kesembilan. Jakarta: Kencana.

Davis, Keith. (1962). Human Relations At work. Universitas Michigan : McGraw-Hill. Effendy, Onong Uchjana. (1986). Hubungan Masyarakat Suatu Studi Komunikologis. Bandung: PT Remaja Rosdakarya..

Felisia, Darjono Yosicho. (2015). Evaluasi Program Employee Relations Toyota Asri Motor Tahun 2015. Jurnal E-Komunikasi Vol 4. No.1.

Jefkins, Frank. (1996). Public Relations. Jakarta: Erlangga.

Moleong, L. J. (2002). Metode Penelitian Kualitatif. Jakarta: Remaja Rosda Karya.

Moore, Frazier. (1981). Public Relations: Principle, Cases, and Problem. New York: Richard Irwin Inc.

Morissan. (2010). Manajemen Public Relations. Jakarta : Prenada Media Group.

Muhammad, Arni. (2001). Komunikasi Organisasi.Jakarta : Bumi Aksara. Hal 107126.

Ningsih, Sri Limanti Yuniarti., Puji Lestari dan Edwi Arif S. (2009). Strategi Employee Relations Untuk meningkatkan Kinerja Karyawan dan Citra Pada PT. Kereta Api (Persero). Jurnal Ilmu Komunikasi, Volume 7, Nomor 2..

Pace, W. R., \& Faules, D. F. (2001). Komunikasi Organisasi : Strategi Meningkatkan Kinerja Perusahaan. (E. Mulyana, Penyunt.) Bandung: Remaja Rosda Karya.

Putriani, Yusia. (2017). Peran Employee Relations Dalam Upaya Pencapaian Visi dan Misi Best Western Premier Solo Baru. Jurnal Humaniora Yayasan Bina Darma, Vol IV, No2. Rachmadi. (1996). Public Relations. Jakarta: Gramedia. Hal. 18.

Rahmi, Hannyy dan Priyo. (2018). Strategi Employee Relations Management Di PT. Kemfarm Indonesia. Jurnal Komunikasi dan Media Vol. 2 No2..

Rakhmat, Jalaluddin. (2008). Psikologi Komunikasi. Bandung: PT Remaja Rosdakarya.

Ruslan, R. (2012). Humas dan Manajemen Komunikasi (Konsep dan Aplikasi). Jakarta: Rajagrafindo Persada. 